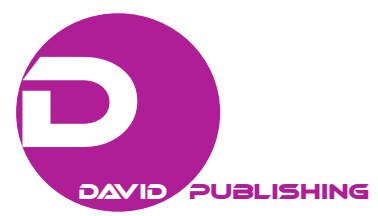

\title{
Ethical Considerations in Undertaking Research in Higher Education: East African Context
}

\author{
David Kipkasi Kessio, John Koskey Chang’ach \\ Moi University, Eldoret, Kenya
}

\begin{abstract}
It is incumbent upon educational researchers to ensure that they uphold ethical considerations while conducting their studies for the findings to be trustworthy and valid. This paper enumerated ethical consideration in data collection, principal ethical issues in human subject, identified ethical concerns in report writing and presentations, and established emerging internet research and ethical research practice. The target population was international students enrolled in selected universities in Uganda. The study adopted a mixed methods design. The method for sampling adopted was both random and purposive. The Cronbach's alpha results obtained from the solutions statistical package for the social sciences (SPSS) platform output were 0.8432 , which was considerably reliable for the study. The research instruments included questionnaires, interview schedule, focused group discussions (FGD), and document analysis. The key informants were interviewed and documents were coded and analyzed thematically. The study revealed the key ethical considerations adhered in data collection, ethical issues in human subjects not often followed and; guidelines for report writing and final presentations. Results from the study would be of significance to researchers, practitioners and policy makers as they conduct studies within evolving educational context.
\end{abstract}

Keywords: ethical considerations, informed consent, Internet research

\section{Introduction}

Educational research as a social science entails people's interaction thus ethical dimensions and considerations are ubiquitous (Kris \& Alison, 2009; Howe \& Moses, 1999; Pittenger, 2003). Researchers ought to be cognizance of laws, rules, including codes of conduct which determine the entire research process (Kessio, 2019; Pittenger, 2003). Researchers should act ethically and abide by ethical guidelines (Howe \& Moses, 1999; Ross, 2005; Dew, McEntyre, \& Vaughan, 2019).

Kris and Alison (2009) summarized key areas where educational researcher has explicit and implicit responsibility to adhere to: area of knowledge, fellow researchers, participants, and lastly, sponsors/administrators/teachers/beneficiaries.

There are several ethical issues that were considered in this particular study in order to adhere to stipulated ethical guidelines and protect students who were the main unit of analysis. It was borrowed from the Belmont Report (1979) and Mcmillan (2012) in British Educational Research Association, 2018 and others who had

David Kipkasi Kessio, Ph.D., lecturer, Department of Educational Management and Policy Studies, Moi University.

John Koskey Chang'ach, Ph.D., associate professor, Department of Educational Foundations, School of Education, Moi University. 
developed from the Belmont Report (1979). Therefore, the study sought to examine ethical considerations in undertaking higher educational research within East African context.

\section{Methodology}

The entire study adopted a mixed method since both quantitative and qualitative data was sought. However, this paper presents qualitative findings (Ross, 2005). It is more than simply collecting and analyzing both kinds of data; it also involves the use of both approaches in tandem, so that the overall strength of a study is greater than either qualitative or quantitative research (Creswell \& Plano Clark, 2007; Pittenger, 2003; Bryman \& Burgess, 2007).

The target population comprised of 936 Kenyan university students enrolled in Ugandan universities, namely: Bugema, Kampala International University (KIU), Kampala University, and Makerere University, which the later was used in piloting. Students constituted the unit of analysis. The other respondents who were interviewed in this study were the officers in charge of academic, security, international students' office, accommodation, and government officers like the personnel in charge of higher education and educational attaché based in the High Commission to Kenya and Uganda, Ministry of foreign Affairs in both countries on policy issues and implementation in higher education. Commission for University Education (CUE), Uganda National Commission for Higher Education (UNCHE), and Inter-University Council for East Africa (IUCEA) were also interviewed as they were involved the higher education in the East Africa region.

In this study, students in their respective universities selected were sampled according to their years of study, degree programmes which the respondents were registered. This provided an overview of the entire population under study through probability sampling. The following data collections instruments were used in this study: questionnaires, document analysis, focused group discussions (FGD), and interview schedules as means of data collection instruments.

Face validity in the study is a component of content validity and is established when an individual reviewing the instrument establishes that it measures the characteristic of phenomenon under study (Ross, 2005). Pilot study in university that did not participate in the study yielded Cronbach Alpha results of 0.8446, thus, acceptable as supported by empirical findings by (Ross, 2005; Creswell, 2012; Mukhopadhyay, 2000). Permission was sought from respective universities and relevant authorities.

\section{Results}

Research findings indicate ethical considerations are ubiquitous while undertaking research. It is supported by other anecdotes and empirical findings that educational research ought to respect autonomy, privacy, diversity, and dignity thereof of participants as either individuals or groups. Research should be conducted with integrity in due considerations of appropriate method for research purpose (Nalita \& Hugh, 2007).

\section{Ethical Consideration in Data Collection}

The study enumerates key considerations upheld during data collection processes. Christians (2000) delineates the four key guidelines adhered during educational research, namely, informed consent: voluntarily participation, this agreement must be based on full and open disclosure; deception, explicit misrepresentation is forbidden; privacy and confidentiality, privacy safeguard against unwarranted exposure, no one neither deserves harm nor embarrassment as a result of research malpractices; and lastly, accuracy including fidelity to research (Mcmillan, 2012; Nalita \& Hugh, 2007). Educational researchers should uphold social responsibilities 
in conducting and dissemination of their findings (British Educational Research Association [BERA], 2018; Taylor \& Bogdan, 2008).

Authorization to carry out the study was sought from National Council for Science and Technology (NCST) who issued research permit and introductory letter to the concerned universities. Clearance from the Ugandan High Commission and other relevant authorities was also sought. This is due to the fact that this study involved two countries and the respondents include Inter-University Council of East Africa (IUCEA), Commission for Higher Education (CHE), government, and respective university officials. The necessary travel documents and permit were sought.

\section{Underlying Ethical Issues in Human Subject's Research}

Educational investigator obtained informed consent from each research respondent through introductory letter and oral consents as appropriate. The respondents had the opportunity to assent to inform consent. The investigators took into consideration the safety of the respondents especially students who were vulnerable. This was addressed by careful consideration of the underlying concerns in higher educational research. The researcher delineated how privacy and confidentiality concerns were addressed in the study (Belmont Report 1979, Kessio, 2019; Bordens \& Abbot, 2011; Ross, 2005; Mcmillan, 2012). Justice was also upheld, thus, participants or beneficiaries should accrue feasible benefits from the research.

\section{Considerations of Ethical Informed Consent for Study Research}

Ensure confidentiality or anonymity of the respondents during the research process and after should be upheld (Taylor \& Bogdan, 2008; Ross, 2005; Nalita \& Hugh, 2007). Familiar diction was embraced during the entire research process and clarifications offered when sought by the respondents (Belmont Report, 1979; Mcmillan, 2012). This is supported by Kessio (2019) and Bordens and Abbot's (2011) findings that the research study should adhere to the Belmont Report (1979, as cited in Christian, 2000; Creswell, 2012), which reiterate three key guidelines that apply to all research that deal with human participants.

In regards to respect for person's, states research participants should be autonomous and allowed to make their own decisions and that participants with limited autonomy in this case students deserve special treatment. Beneficence intimates that research participants must have their well-being protected always. Beneficence embodies two elements: do not harm and maximize benefits while minimizing harms (Bordens \& Abbot 2011). Justice divides the burdens and benefits equally between the researcher and participants.

\section{Ethical Concerns in Report Writing and Presentations}

All respondents enrolled in higher education institutions just like other international students were living in a social political context in a foreign country, Uganda and thus needed to be assured of safety from harm as a result of research process as supported by findings from Bordens and Abbot (2011).

They needed to be assured that publication of the study findings where such information could be used in ways that carry reputational risks for providers, students, and staff, publication of entry, publication of blacklist of disreputable or non-accredited providers would have had to be agreed upon and was not the mandate of the study at that particular time (Stensaker \& Harvey, 2011). This was upheld in this particular research as the findings was solely used for research purpose and disclosure principles respected (Nalita \& Hugh, 2007; Ross, 2005).

There is also need for researchers to refrain from research malpractices. Research misconduct entails both the treatment of study participants who were vulnerable students; and overt fraudulent or deceptive practices 
during research and reporting (Howe \& Moses, 1999). It is instructive to not that even when having no direct effect on research participants, research misconduct nonetheless wrongs others within the research community and damages the research enterprise overall

\section{Research Fraud}

The Office of Research Integrity (ORI) (2009, p. 2) defines three categories of research fraud:

1. Falsification: manipulating research materials, equipments or processes or changing including omitting data or results such that the research is not accurately represented in the research record;

2. Data fabrication: making up data or results and reporting on them;

3. Plagiarism: the appropriation of another person's ideas, results, or words without giving appropriate credit through acknowledgement, references, and sources.

FGD with the students and interview with officers from commission for university education obtained from thematic coding reiterated that the following are the common ethical issues in higher education research:

1. Research process and fraud: publication, for example, in predatory journal and students work/others without prior consent;

2. Supervision of post graduates and thesis examination: bias, integrity, or ethical concerns.

Table 1

Reasons for Academic Fraud and Solutions

\begin{tabular}{|l|l|}
\hline Reasons for academic fraud as ethical issues & Dealing with fraud and ethical issues \\
\hline Fraud perpetrated for personal recognition, for example, & Train students in the ethics of research; \\
publication in prestigious journal; & Let researchers learn early about scientific integrity in research; \\
Pursuit for income. & Students should be taught ethical issues correctly; \\
Tenure or promotion criteria in an academic environment: & Make it clear that they will be caught and institute measures; \\
publication in refereed journal; & Contact research participants; \\
Relaxed environment, lack of punitive measures against fraud. & Discern strange data and report. \\
\hline
\end{tabular}

\section{Discussion}

Findings from Bryman and Burgess (2007), aptly puts that researchers are often involved some research activities that entail explicit or implicit negotiation, thus, assurances that researcher would not violate respondent privacy or confidentiality, neither expose them to unnecessary harm nor infringe in their activities (Taylor \& Bogdan, 1998; Belmont Report, 1979; Mcmillan, 2012; Battiste, 2008). In this study, issues on social economic challenges, existing policies guiding higher education, quality of the programmes to the effect that their qualifications. That institution may not have been accredited or recognized by employers required tact on the side of the researcher and more so trust by the respondents (Creswell, 2012).

The researchers upheld ethical considerations throughout research process and informed consent were sought as it was appropriate. Content and document analysis revealed what constitutes fraud in research as follows: data fabrication, falsification, and plagiarism. This supports the findings from (ORI, 2009; Battiste, 2008; BERA, 2018).

Internet is commonly used in research thus offers contemporary way to conduct educational and social science research. Use of internet to undertake research study complicates the study due to presence of hackers and prone to malpractices (Bordens \& Abbot, 2011). It is evident from the study and other empirical studies that some internet research entails a participant assessing a website to undertake a study (Cohen, Bankert, \& Cooper, 2005; BERA, 2018). It is useful when ethical concerns are adhered to. 
On the other hand, another form of internet involves issues not covered by existing ethical guidelines: How do you obtain informed consent from the chat room participant? How do you protect the privacy and confidentiality of research participants online? There could be need to assign pseudonyms to participants who agree to remain in chat rooms.

\section{Conclusions}

It is evident that that the following key variables are inevitable while conducting educational research: Firstly, ethical consideration in data collection through adherence to research protocol of clearance by relevant institutional bodies; secondly, principal ethical issues in human subject: respect for persons; beneficence and justice. During report writing and presentations stage; it is apparent that instances of plagiarism are perhaps the most common of all research misconduct in educational research.

Plagiarism may constitute various forms: lifting researcher's work or verbatim, it is clandestine. Infringe of intellectual property without making reference or express permission of the originator of those ideas; or lifting avalanche portions of another's research without due acknowledgement. Lastly, Internet use in research is now common and researchers should understand that it does not afford privacy since it can be hacked. Anonymity can be maintained by use of pseudonyms.

The findings from this study would therefore be of significance to researchers, practitioners and policy makers in order to design and conduct ethically informed research within educational context, thus sound and feasible outcomes.

\section{Recommendations}

The following recommendations were derived from the research study:

1. There is need to adhere to ethical consideration in data collection through education, embedding them in research guidelines and protocol including Institutional Review Board (IRB) in addition to research authorization by relevant regulatory bodies;

2. Principal ethical issues that relate to human subject should be followed and enforced throughout educational research process: respect for persons, beneficence and justice;

3. Report writing should follow accepted guidelines, references frankly delineated and presentations made;

4. Researchers should adhere to best practice in internet research and observe ethical practice.

\section{References}

Battiste, M. (2008). Research ethics for protecting Indigenous knowledge and heritage: Institutional and researcher responsibilities. In K. D. Norman, S. L. Yvonna and T. S. Linda (Eds.), Handbook of critical and Indigenous methodologies (pp. 2-19). Thousand Oaks, CA: Sage.

Belmont Report. (1979). Ethical principles and guidelines for the protection of human subjects of research: The National Commission for the Protection of Human Subjects of Biomedical and Behavioral Research, Department of Health, Education, and Welfare, Superintendent of Documents. Washington, DC: U.S. Government Printing Office. Retrieved from http://www.hhs.gov/ohrp/humansubjects/guidance/belmont.htm 1/12/2019

British Educational Research Association (BERA). (2018). Ethical guidelines for educational research (4th ed.). London. Retrieved from https://www.bera.ac.uk/researchers-resources/publications/ethical- guidelines-for-educational-research-2018 Borens. S. K., \& Abbot, B. B. (2011). Research design and methods: A process approach (8th ed.). McGraw-Hill, New York. Bryman, A., \& Burgess, R, G. (Ed.). (2007). Analysing qualitative data. Routledge, New York.

Christians, C. G. (2000). Ethics and politics in qualitative research. In N. K. Denzin and Y. S. Lincoln (Eds.), Handbook of qualitative research. London: Sage Publications. 
Cohen, J. M, Bankert, E., \& Cooper, J. A. (2005). History and ethics. McGraw-Hill, New York.

Creswell, J. W., \& Plano Clark, V. L. (2007). Designing and conducting mixed methods research. Thousand Oaks, CA: Sage.

Creswell, J. W. (2012). Designing and Conducting Mixed Methods Research (2nd ed.). Thousand Oaks, CA: Sage

Dew, A., McEntyre, E., \& Vaughan, P. (2019). Taking the research journey together: The insider and outsider experiences of aboriginal and non-aboriginal researchers. Forum: Qualitative Social Research, 20(1), 1-17.

Howe, K., \& Moses, M. (1999). Ethics in educational research. Review of Research in Education, 24, 21-60.

Kessio, D. K. (2019). Peer mentoring and its implications in students support and management in secondary schools in Kenya: A case of Friends School Kamusinga (FSK), Bungoma County, Kenya. Journal of Education and Practice, 10(35), 63-69. Retrieved from https://www.iiste.org/Journals/index.php/JEP/article/view/50864

Kris, S., \& Alison, F. (2009). Ethics in educational research: Introducing a methodological tool for effective ethical analysis. Cambridge Journal of Education, 39(4), 489-504. DOI: 10.1080/03057640903354396

Mcmillan, J. H. (2012). Educational research fundamentals for the consumer (6th ed.). Boston: Pearson education, Inc.

Mukhopadhyay, N. (2000). Probability and statistical inference. New York: Marcel Dekker, Inc.

Nalita, J., \& Hugh, B. (2007). Ethical issues in online educational research: Protecting privacy, establishing authenticity in email interviewing. International Journal of Research \& Method in Education, 30(1), 101-113. Retrieved from http://Collections.Lib.Uwm.Edu/Cipr/Image/479.Pdf

Office of Research Integrity (ORI). (2009). Handling misconduct-complainant. Retrieved from http://ori.hhs.gov/misconduct/whistle-blowers.shtml

Pittenger, D. J. (2003). Internet research: An opportunity to revisit classic ethical problems in behavioural research. Ethics in Behaviour, 13, 45-60.

Ross, K. N. (2005). Quantitative research in educational planning. Paris, France: UNESCO International Institute of educational Planning.

Stensaker, B., \& Harvey, L. (Eds.). (2011). Accountability in higher education: Global perspectives on trust and power. London: Routledge.

Taylor, S. J., \& Bogdan, R. (2008). Introduction to qualitative research methods (3rd ed.). Canada: John Wiley \& Sons, Inc. 